\title{
ETCS Experiences in Zoology: under and postgraduate courses
}

\author{
María-Isabel Arnaldos and María-Dolores García \\ University of Murcia \\ Spain
}

\section{Introduction}

The process of Convergence of the higher education in Europe is being developed from an initial agreement among universities and, later, linked to the political compromise of the different member states. This system tries to overcome the existing normative, bureaucratic and focalization particularities of higher educational systems of the different States, which, up to now, make impossible the free traffic of professionals and students through the European Area.

The process of Convergence, among others, implies the adoption of the European Credit Transfer System (ECTS), which represents, first of all, a new perspective of the university professional training, based on the training through competences, that is, the acquisition of the knowledge, skills and attitudes necessary to fulfil successfully the aims proposed in the different matters of the university degrees.

Secondly, the ECTS constitutes a system of automatic recognition of credits among the different Universities which will go well together to the accreditation of the degrees) granted by them. The basic unit of this system is the so called European Credit, that the Spanish regulation (RD 1125/2003 of September 5 (BOE not. On September 224, 18, 2003) defines like "... the unit of academic measure that represents the quantity of work that the student needs to fulfil the aims of the studies program... ("... la unidad de medida académica que representa la cantidad de trabajo que requiere el estudiante para cumplir los objetivos del programa de estudios... En esta unidad de medida se integran las enseñanzas teóricas y prácticas, así como otras actividades académicas dirigidas, incluyendo las horas de estudio y de trabajo que el estudiante debe realizar para conseguir los objetivos formativos propios de cada una de las materias..."). This simple definition has a few deep implications in the teaching-learning process of the Spanish university.

Up to now, such a process was generally based in the lectures, where the students perceived, and are still perceiving, the knowledge transferred by the teacher as the unique reality. So, the teacher directs completely the educational process and the student feels as unnecessary anything else than to transcribe the listened to pass the subject. This type of education reaches, even, the practical laboratory activities, though in them the student's own manipulation and observation can be demanded.

This kind of "student - sponge", who ends up by knowing only that has been explained during the lectures, has a very small professional projection. Really, when he accedes to a job is 
when he must develop all those professional competitions that have not been demanded from him before. To a job a "student - sponge" contributes, only, his knowledge, but he has developed neither skills nor the appropriate attitudes.

This circumstance is one of the reasons of the sometimes deep divorce between the current university education and the society, between what a university student offers and what the employers are demanding. Despite this inconvenience, the university student feels the system as comfortable, since he must act as mere recipient, without having to leave a passive attitude, of spectator of what is teaching him. Later, in only a few days or weeks, he tries to assimilate all that that has been explained exposes it in an examination and, he is just a little lucky, he pass the subject.

The problem is that the changes that have to be produced in relation with the European Higher Educational Area (EHEA) Convergence suppose a point of inflexion in the arrangement and structure of the university education. The teachers will have to think seriously and deeply on the subjects, will have to form educational coordinated, responsible and solid teams and develop the programs in a reasoned way, always bearing in mind the degree of learning that the students have to achieve. The students, for their part, will have to be active elements of the learning process, assuming the commitments that every subject of the training program and adopting a working methodology opposite to that they are presently accustomed.

This system will offer guarantees of acquisition of competences of professional type, that is, a student should be able to approach the fulfilment of concrete tasks, close to those that the labour market could demand. In these competences there must meet personal capacities of different type besides basic generic and specific competences of the precise qualification. This implies that be necessary to guarantee the learning of a few contents not lower than those who nowadays could be given but, in addition, must achieve the acquisition of the skills and mental competences of the professional aspect covered by a subject.

We are already near the implementation of the new plans of study, elaborated concerning the ECTS credits and constructed, at least theoretically, from the training for competences. In the Spanish University there has been, in the last years, diverse attempts o implementing or simulating the implementation of the ECTS system, either in complete years, complete qualifications, or free subjects, depending, among others, of the availability of professors in relation with the number of students.

In the Complutense University of Madrid, for example, inside the degree's qualifications in Biology, it is worth of note the experience developed in the subject "Experimental Biology (Organisms and Systems)", where an excellent coordination has been achieved between several "traditional subjects" and new methodologies have been adopted successfully. This subject is eminently practical, and in it an integral learning of the Biology "of field" has been achieved; the student has acquired absolute protagonism in its development and the acquisition of competences.

In the University of Murcia (southeastern Spain), in a general way, the complete implementation have been developed in those grades with very good teachers/pupils ratio, normally because the number of pupils is low. Nevertheless, in grades with a medium or high number of pupils, the simulations have been done in a voluntary and individual way, in free subjects. In principle this is not desirable because it forces the student to coexist with two types of educational strategies completely different. 


\section{Experiences}

In our case, we have taken part in pilot experiences of implantation of the ECTS system in several subjects: optional of degree (Systematic Zoological) and of post degree (Medico - legal Entomology and Entomology applied to the Forensic Sciences). The subjects imply, initially, attending learning but, in case of those of post degree, the semi-attending modality has been tried. In addition, and voluntarily, "European" strategies have been implemented in certain aspects of the theory and in the practical program of Zoology, compulsory subject of the first year of the Biology degree. In this contribution, we present the results obtained in these experiences.

In the subjects in which the experiences have been developed, some or all the following strategies have been implemented:

Development of an Educational Guide for the subject.

Development of didactic scripts of the different themes.

Audio-visual material of help.

Development of a web page for the subject

Utilization of the restricted access virtual campus of the University of Murcia (SUMA).

Design of different proofs for the continuous assessment.

Implementation of a new evaluating system.

Problem or cases based learning.

Use of the student's portfolio.

1) Educational Guide. At least in our near environment, it is a usual practice to develop an educational guide, although people does not matter to take into account for it, or not, the competences to achieve by the student. Simply, it is usually developed in the same way it was done for the subjects programs, that is, arranging sequentially the contents to be treated and making up the whole using some terms of pedagogic type to provide "credibility" to the guide. We were tempted of making the guide like that; because we the scientists are not used to the didactic and pedagogic worries. In our concrete case, the elaboration of the educational guides could begin in the same way, but the process did not have continuity. From a few scientific concrete contents, we tried to construct the subject so that there were reached those competences we considered basic for it, taking into account the different working methods and the evaluation methods to apply. The first thing we had to do was to think carefully about what we pretended the student learns. Our first challenge was to forget what we thought we should teach and start to think about what the student should learn. When we reached this objective, the rest of the work was easier. Summarising, the whole process included from the competences definition to the design of evaluation tools to verify they have been acquired. In the case of the three subjects completely adapted to ECTS methodology, we tried to motivate the self-activity of the student. We tried always to explain gradually all the activities and works to do in order to guide the student's learning process.

In short, the points included in an Educational guide are the following:

Subject identification, including subject title, code, type (optional, compulsory), ECTS credits, length (half-yearly, annual) and language in which it will be explained. These items have to be the usual ones in a guide.

Subject introduction, where there is more information about the fundamentals of the subject, its aim and objectives. 
Previous need knowledge. With this point the student can know its real possibilities to take advantage and pass the course with no more efforts than the required by the own subject.

\begin{tabular}{|c|c|}
\hline \multicolumn{2}{|c|}{ RELATION BETWEEN COMPETENCES } \\
\hline Specific of the Master & Specific of the subject \\
\hline $\begin{array}{l}\text { Getting different evidences } \\
\text { in Forensic Sciences }\end{array}$ & $\begin{array}{l}\text { 3. Apply appropriate collecting and processing methods for } \\
\text { entomological evidences }\end{array}$ \\
\hline $\begin{array}{l}\text { Treatment and } \\
\text { consideration of different } \\
\text { evidences in Forensic } \\
\text { Sciences }\end{array}$ & $\begin{array}{l}\text { 3. Apply appropriate collecting and processing methods for } \\
\text { entomological evidences } \\
\text { 4. Identify the arthropods associated to medico-legal cases }\end{array}$ \\
\hline $\begin{array}{l}\text { Knowledge of the legal } \\
\text { aspects related to the } \\
\text { Spanish probatory system }\end{array}$ & $\begin{array}{l}\text { 1. Appropriate use of scientific terms of entomological field } \\
\text { with correct and fluid oral and writing expression in the } \\
\text { scientific entomological terms } \\
\text { 2. Knowledge of the fundamentals for appñying the } \\
\text { Medico-legal Entomology } \\
\text { 3. Apply appropriate collecting and processing methods for } \\
\text { entomological evidences } \\
\text { 4. Identify the arthropods associated to medico-legal cases } \\
\text { 5. Determine the appropriate use of the different } \\
\text { experimental methods for studying Medico-legal } \\
\text { Entomology } \\
\text { 6. Elaborate expertises in Medico-legal area }\end{array}$ \\
\hline $\begin{array}{l}\text { Elaborate expertises } \\
\text { summary taking into } \\
\text { account the obtained } \\
\text { evidences }\end{array}$ & 6. Elaborate expertises in Medico-legal area \\
\hline $\begin{array}{l}\text { Capability to evaluate a } \\
\text { forensic scene using a } \\
\text { multidisciplinary scientific } \\
\text { approach }\end{array}$ & $\begin{array}{l}\text { 3. Apply appropriate collecting and processing methods for } \\
\text { entomological evidences } \\
\text { 4. Identify the arthropods associated to medico-legal cases } \\
\text { 5. Determine the appropriate use of the different } \\
\text { experimental methods for studying Medico-legal } \\
\text { Entomology }\end{array}$ \\
\hline $\begin{array}{l}\text { Applying the appropriate } \\
\text { analytical techniques to the } \\
\text { different types of forensic } \\
\text { evidences }\end{array}$ & $\begin{array}{l}\text { 3. Apply appropriate collecting and processing methods for } \\
\text { entomological evidences } \\
\text { 4. Identify the arthropods associated to medico-legal cases } \\
\text { 5. Determine the appropriate use of the different } \\
\text { experimental methods for studying Medico-legal } \\
\text { Entomology }\end{array}$ \\
\hline
\end{tabular}

Table 1. Relationship between specific competences of the Forensic Science Master and Medico-legal Entomology subject (Arnaldos \& García, 2008)

Competences. This point can have a variable length, but we think that it has to include, at least, the title generic competences, as well as those defined by the University, the specific of the grade and the specific of the subject. It is advisable to include the relations between all them. 
Table 1 shows one example corresponding to Medico-legal Entomology subject, belonging to the Forensic Science Master (Arnaldos \& García, 2008).

Programme. The different themes can be grouped into thematic blocks, as well as the practical sessions.

Teaching methodology. This point has to summarize the different methodologies applied in every subject. In general, we have attempted to combine efforts both in conceptual understanding and in the implementation and use of knowledge (Coll et al., 2006). As an example, we have implemented such methodologies as lectures in form of oral presentations (for the theoretical themes, using communication and information techniques), case or problem solving learning (in laboratory practice units), tutorials, working groups for cooperative learning, self-evaluation (a commitment of the student himself) and co-evaluation (in the sense of Topping, 1998). The case solving learning aims to transform the student, the beginner, into an expert, who will consider the data more useful for solving a problem case (see Cortés García et al., 1998). The self-evaluation can be considered a learning tool, a part of the teaching process (Jiménez Valverde, 2000), because the vision of the student as an evaluator is closest to its own prospects (McConnell, 2000). In the case of the Medico-legal Entomology, it can be applied to the expertises, which will be presented to evaluate the synthetic capacity of the student, its oral capabilities and finally, if discussion arrives, its familiarity with the subject (Arnaldos \& García, 2008). This point should include, as a different paragraph, the distribution of the work load of the student expressed in hours. Table II shows an example.

Chronological display. This aspect has to be intimately related to the previous one; it can be exposed in a simple way (i.e., a table), but the student has to be sure about when each learning activity will be developed.

ECTS work load. This point informs the student about what will be the distribution of his work load expressed in hours (Table 2). It is understood that an ETCS credit equals 25 work hours of which up to $40 \%$ must require the presence of the student. This is the way in which both the teachers and the students have under control the efforts they do in a concrete subject. Students' evaluation. Here all the aspects of qualification of the subject must be clearly exposed, in a way in which the student knows the criteria to be applied in every considered tool (tests, lectures, expertises, ...) and the relative value respect to the final qualification.

Literature, which should include the basic one, that is, the considered as necessary to develop in the right way the subject. It also can include more specific and advanced, depending on the level in which the subject is.

The Guide usually includes other items, such as the way in which the course will be evaluated.

2) Didactic scripts of the units/themes. This is a very advisable way to keep informed the student about the development of the course. The scripts should include the main items to be explained during the classes, the materials to work with during practices and the most relevant literature (papers, books, URLs,...) related to the theme. Other information, such as the principal scientific terms that the pupil must incorporate into his Glossary, can also be included. Figure 1 shows an example of didactic script. The scripts are progressively available through the virtual campus of the University of Murcia (SUMA). 


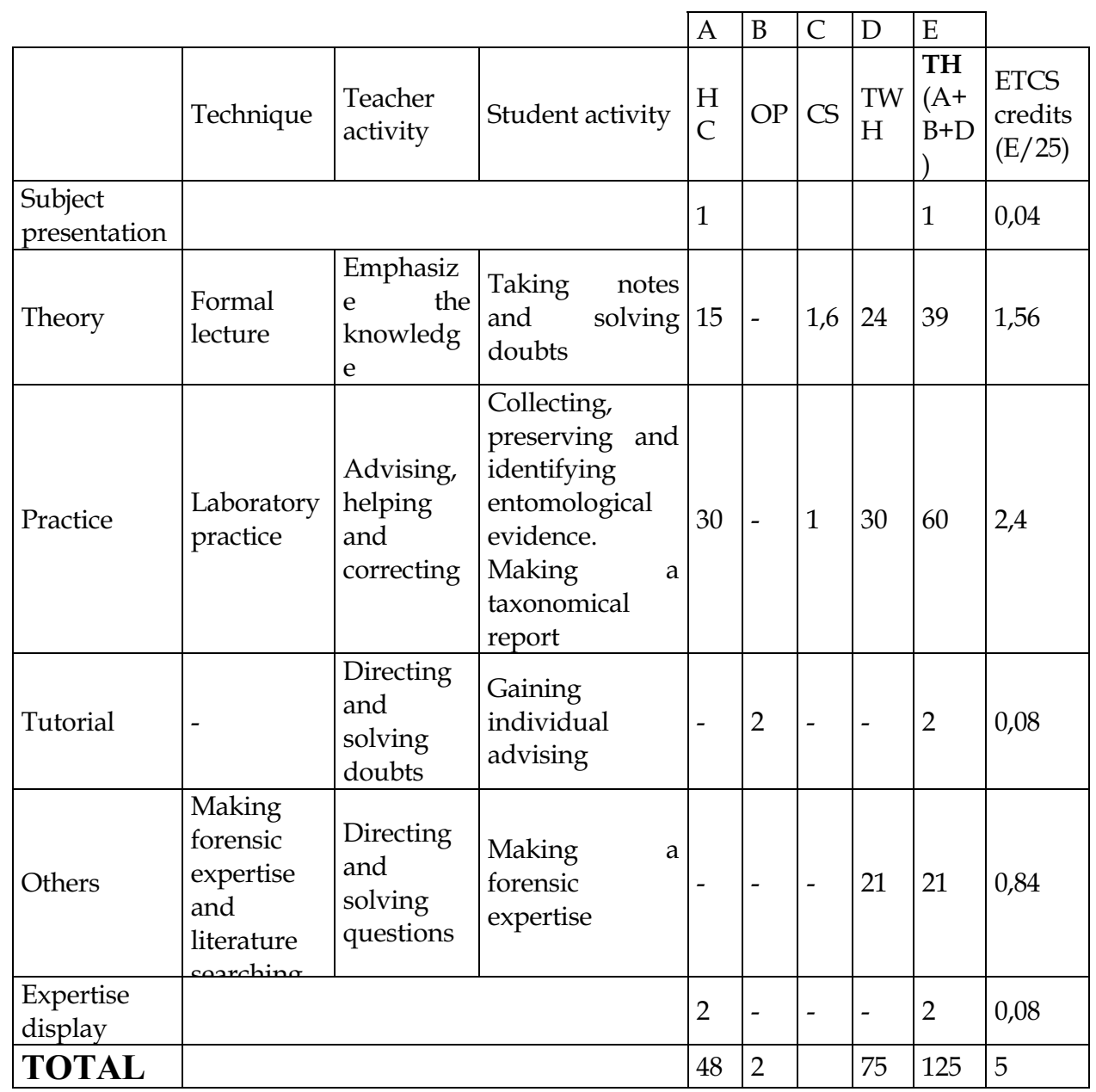

Table 2. ECTS work load for Medico-Legal Entomology subject of the Forensic Science Master (Arnaldos \& García, 2008). HC: hours in classroom, OP: other live hours, CS: Coefficient of study, TWH: total working hours, TH: total hours

3) Audio-visual material. SUMA will hold the main visual support used during lectures in order to the student can follow-up the lectures easier. Also, the student can access to useful materials for practical classes, such as identification keys, photographs of different specimens or simulations of identification, among others. A CD-ROM has been published "visually" developing the practical classes of the subject Zoology (García et al., 2007) and performing a virtual laboratory where the student can return to review the materials, fix concepts, solve doubts,... This has been the complement of a practical guide published before (Romera Lozano et al., 2003) which tries to guide the students all along the practical classes doing them relate the texts they are reading and the images they are watching at the lab. Other materials, as species identification cards (Andreu et al., 2005), have been published as a help to prepare the visu test in Zoology subject. 
4) Web pages. For some subjects a simple web page has been constructed in order to provide all the information about them and, gradually, specific materials, as well as links with other interesting pages or materials. These web pages are usually available through SUMA.

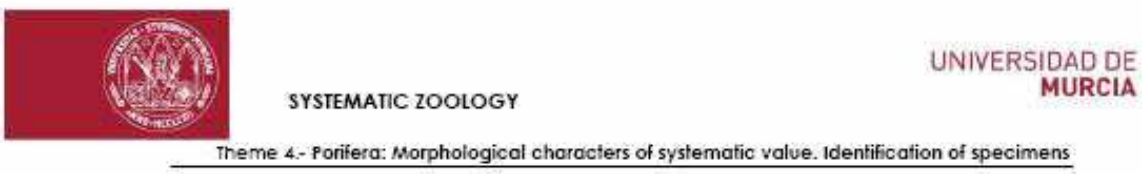

\begin{tabular}{l} 
THEME'S CONTENTS \\
INTRODUCTION \\
CASIFICATION OF PHYLUM PORIFERA \\
CHARACTERS OF SYSTEMATIC VALUE: \\
Spicules, characteristics, clasification and terminology \\
Spongin fibers, characteristics and terminology \\
\hline
\end{tabular}

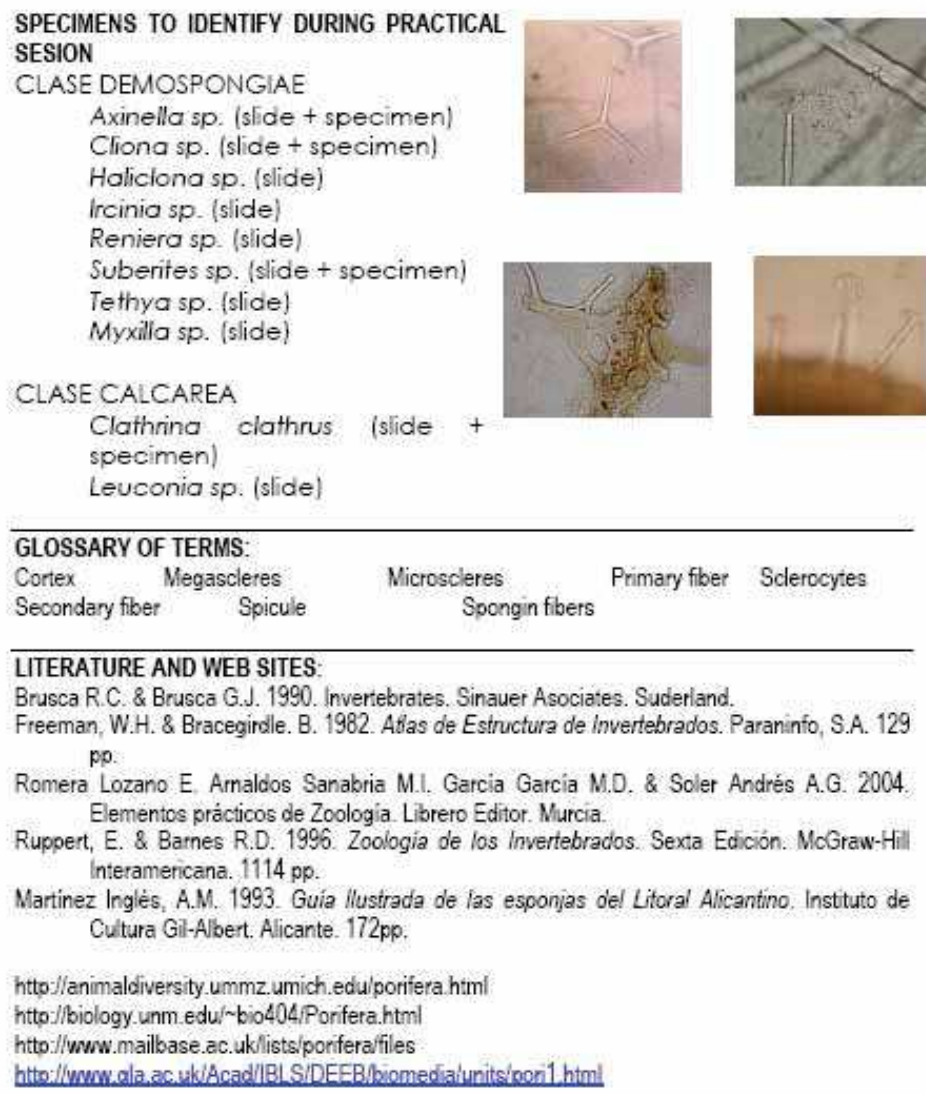

Fig. 1. Didactic script of a didactic unit belonging to Systematic Zoology subject. 
5) SUMA. As said above, the virtual campus of the University of Murcia (SUMA) is the channel of communication normally used. This is one way to ensure the students acquire competences in TICs.

6) Continuous assessment. Several types of tests and proofs for a continuous assessment have been established. All of them imply the existence of feedback that allows the student to know the degree of kindness of the work done. Proofs are, among others, a glossary of terms, several tests during the classes and practice notebooks review. All them, once corrected, are returned to the student in order to verify the reached level and to rectify, if necessary, the way to work or study. On the other hand, all tests and works must be kept as part of the Student Portfolio and presented, as a whole, at the end of the course.

With this way to evaluation, the student does not depend on an unique final examination to overcome the subject, but he is continuously getting points which will be considered, as established in the evaluation system of the Educational Guide explained above. The final examination will offer a global idea of the level achieved by the student but, due to the fact that its results can be affected by multiple factors, the qualification will not be the one that defines the qualification of the course, but one more. Another method is the participation in seminars (work in group), where the students have to exhibit oral skills and demonstrate their capacity of synthesis and control of the topic. Following the oral session, every student has to fill a form of self-evaluation and a form of co-evaluation (inter pares), to think critically about the participation of all the people and to assume the own (proper) responsibility, leading to a experience based learning.

7) Problems (PBL) or cases (CBL) based learning. This is the method applied to the laboratory practices of certain subjects (Systematic Zoology, Medico-legal Entomology). In them, the pupil must identify the specimens problem or solve practical "cases". For it, the student can use all kinds of information (notes of class, books...) as well as technical material (keys of identification). Following Cortés García et al. (1998), the PBL or CBL can transform the student into expert, that is, who will take into account the most useful data in order to identify the relevant data of a problem. It is a proved fact that the students learn much more during the practical classes. Through the PBL or CBL the students develop better their mental capacities evaluating real situations and applying concepts that memorizing the same concepts from said during lectures. In our case, with this method they assimilate better the zoological concepts used during the resolution of the real problems (animals to identify, for example), and helps them to develop skills as the capacity of observation of the reality and environment and the adoption of decisions. This method allows to verify the competence level achieved by the student because solving a problem (or case) implies that the student knows (concepts, scientific terms,...), knows how to do (manipulates correctly the material, locates the taxonomic characters, understands scientific texts...) and knows how to be (developing personal initiatives to search complementary information, acquiring correct habits of work at the lab,...).

8) Student's portfolio. This is neither an assessment nor a learning method itself but a way in which the students have to assume the responsibility of keeping and taking care of all the materials they have done along the year or semester and of presenting them in a convenient way to can be considered, as a whole, to get a mark. The portfolio can also include the so called Student's note book where the students are asked to complete the efforts (measured in spent hours) applied in every activity (during a week, a day...). 


\section{Results}

In our case, we have taken part in pilot experiences of implantation of the ECTS system in several optional subjects, of grade (Systematic Zoological) and of post grade.

\section{OPINION POLL FOR STUDENTS OF SYSTEMATIC ZOOLOGY}

Date:

The Zoology Area of the Department of Zoology and Physical Anthropology of the University of Murcia take part in the Educational innovation project related to the European Convergence. We are getting some information about the student work load to pass the subject Systematic Zoology once adapted to the ECTS methodology. We ask you for your sincere answer to this anonymous enquiry, pointing at the number of hours of personal work devoted to every activity you did. You have not to include the assistance to lectures, practical lessons and seminars. At the end of the enquiry you'll find some questions to evaluate your satisfaction with your learning process and the degree of difficulty you find in this subject

Subject: SYSTEMATIC ZOOLOGY; Code: 09B7; Type: OPTATIVE

Course: First Cycle of Biology degree

Length: $2^{\text {nd }}$ TERM, Credits: 1,5 Theory +3 Practices

\begin{tabular}{|l|l|}
\hline $\begin{array}{l}\text { During last week, how many hours of personal work have you } \\
\text { devoted to every activity of the following: }\end{array}$ & Hours \\
\hline Theory (study, class notes organization, documentation,...) & \\
\hline Glossary & \\
\hline Study before practical lesson & \\
\hline Internet search & \\
\hline Others (specify) & \\
\hline Tutorial & \\
\hline
\end{tabular}

Up to now:

You think that your learning with ECTS methodology is higher than with the traditional methodology (lectures and final examination)

Value the degree of difficulty to pass the subject with the ECTS methodology compared to the traditional methodology

You study day by day, you attend the practical lessons knowing the basic concepts to apply, you usually prepare the materials of the subject

The knowledge you receive in both lectures and practical lesson is useful to develop scientific and professional competences

You are feeling that you develop step by step the competences described in the Educational Guide

\begin{tabular}{|c|c|c|c|c|c|c|}
\hline $\begin{array}{l}\text { Absolute } \\
\text { disagree }\end{array}$ & 1 & 2 & 3 & 4 & 5 & $\begin{array}{l}\text { Absolute } \\
\text { agree }\end{array}$ \\
\hline $\begin{array}{l}\text { Little } \\
\text { difficulty }\end{array}$ & $\begin{array}{l}1 \\
0\end{array}$ & 2 & $\begin{array}{l}3 \\
\square\end{array}$ & $\begin{array}{l}4 \\
0\end{array}$ & $\begin{array}{l}5 \\
\square\end{array}$ & $\begin{array}{l}\text { Higher } \\
\text { difficulty }\end{array}$ \\
\hline $\begin{array}{l}\text { Absolute } \\
\text { disagree }\end{array}$ & $\begin{array}{l}1 \\
0\end{array}$ & $\frac{2}{0}$ & $\begin{array}{l}3 \\
0\end{array}$ & 4 & 5 & $\begin{array}{l}\text { Absolute } \\
\text { agree }\end{array}$ \\
\hline \begin{tabular}{|l} 
Absolute \\
disagree
\end{tabular} & 1 & 2 & $\begin{array}{l}3 \\
\square \\
\end{array}$ & $\begin{array}{l}4 \\
0 \\
\end{array}$ & $\begin{array}{l}5 \\
0\end{array}$ & \begin{tabular}{|l} 
Absolute \\
agree
\end{tabular} \\
\hline $\begin{array}{l}\text { Absolute } \\
\text { disagree }\end{array}$ & 1 & $\bar{c}$ & 3 & 0 & 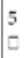 & $\begin{array}{l}\text { Absolute } \\
\text { agree }\end{array}$ \\
\hline
\end{tabular}

REMARKS:

Fig. 2. Opinion poll carried out in Systematic Zoology subject. 
Also we have adapted, though partially, an obligatory subject of grade (Zoology). The results of the different adopted actions have been evaluated, mainly through satisfaction opinion polls among the students, an example of which can be seen in Figure 2.
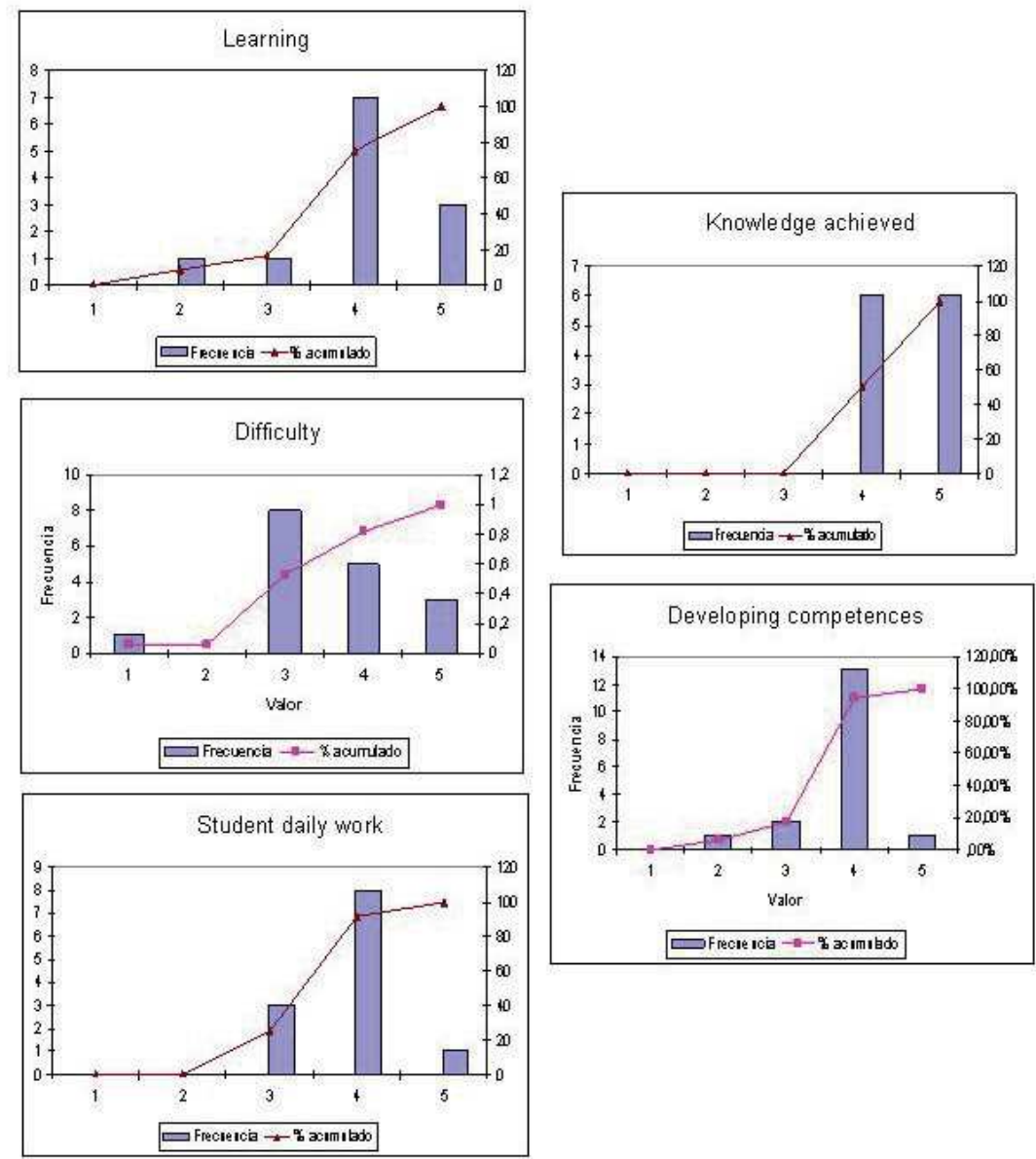

Fig. 3. Results of the second set of questions of the opinion poll carried out in Systematic Zoology subject.

It is obvious that the level of maturity of the students is not the same when comparing grade and postgraduate courses and, even inside the grade it is different between the first and the last courses. Because of that, results of satisfaction are not exactly the same, but in all the cases results obtained show a high degree of satisfaction with the applied methodology. As an example, Figure 3 shows the results corresponding to the second questions set of the opinion poll cited above. As can be seen, the students appreciate the achieved with the ECTS methodology learning level and knowledge, and feel they develop the expected competences. About the difficulty of the subject when applying the ECTS methodology, they think it is not 
special, but the students complain about the amount of work the new methodologies represent for them. This point is especially relevant in order to programme all the learning activities in all the subjects of an academic course.

On the other hand, the success obtained by the students when applying the ECTS methodology has been highly upper than before, with we used the traditional methods. Respect to the marks obtained by the students the experience shows that who has followed the working rhythm has passed satisfactorily the subject and, as a consequence, the success rate has remarkably increased. Thus, in the case of a grade compulsory subject of first course (Zoology), the methodology has had as a consequence that the students are progressively attracted by the subject and feel its learning as more useful and interesting for their professional development. These points are shown in the opinion polls periodically made (Ubero et al., 2008). In the case of a grade optional subject (Systematic Zoology), not only the results of opinion polls are good but also the number of students who pass the subject has increased to a great extent, reaching the $100 \%$ of success the last year. Nevertheless, the students feel this methodology means an extra effort in comparison with their "normal" learning process, more passive, to which they are habituated.

The post graduate courses have a different point of view. First of all, the students show a great interest because they are older and, thus, more mature, they are usually working and value in a different way the efforts to improve their learning. They try to participate actively during the lectures and interaction between teachers and them enriches their learning and the own methodology.

From the teachers' point of view, the new methodology involves a superior dedication to the teaching activities. The principal difficulty they find is the increasing amount of work because, apart of the lectures themselves, or the practical lessons, many time has to devote to other teaching activities such as seminars, tutorials to little groups, supervising proofs and informs,... In addition to that, the scientific teachers need learning in didactic ECTS methodologies what supposes an additional effort difficultly compatible with the researching activities. Our experience shows that all these works represents a $70 \%$ of additional devoted time respect to the same subject explained in a traditional methodology.

On the other hand, especially in the degree subjects, the teachers estimate a low level of response among the students and are worried for the scanty employment of the tutorials, attending or not.

Nevertheless, the developed experiences have turned out to be useful, since they have served as diagnosis of needs and lacks of organizational and institutional type. For us, as teachers we are, the experiences have been very useful in order to know in advance the educational tasks that can and must be associated to the ECTS credit. On the other hand, we have developed skills and attitudes in relation with them, especially in the design of the educational guides, where a fundamental role plays the design of the specific competences in relation with the degree competences.

\section{Future challenge}

As a next future challenge, we consider very interesting to develop virtual learning skills and, among them, to participate in the Open Course Ware (OCW) as a platform where the virtually materials related to Zoology subjects contents can be published. This format is especially pleasant to the students, who are much habituated to use computers, web pages and the web 
as a whole. For them, the OCW seems to be a permanent classroom where they can find audiovisual materials to insist on their previously acquired knowledge. This kind of materials assures the possibility of autonomous and long-life learning, two of the main goals of the EHEA principles. At this respect, we will next prepare the materials related to Systematic Zoology and Medico-legal Entomology and, also, a revised and updating edition of practical guide of Zoology adapted to the new degree of Biology.

Apart of that, the most important challenge for us the teachers will be the successful start of the Convergence process, that involves both academical and political efforts, mainly to provide enough financial supports in order to carry out such a high teaching dedication and special attention to the students.

\section{References}

Andreu, A., Arnaldos, M.I., Romera, E., Collantes, F., Ubero, N., Clemente, M.E., García, M.D. y Presa, J.J. 1998. Diversidad Animal. Fichas para el reconocimiento de especies. Vol. I y II. 777 págs. D.M. Librero Editor. Murcia. I.S.B.N. (obra completa): 84-95095-15-7.

Arnaldos, M.I. \& García, M.D. (2008). ETCS experience in postgraduate courses: Medico-legal Entomology subject, In: INTED 2008 Proceedings CD. Iated (ed.), ISBN: 978-84-6120190-7, Valencia.

Coll, C., Mauri, T. \& Onrubia, J. (2006). Análisis y resolución de casos-problema mediante el aprendizaje colaborativo. Revista de Universidad y Sociedad del Conocimiento, 3, 2: 29-41. ISSN: 1698-580X.

Cortés García, U., Moreno Ribas, A., Armengol Volta, E., Béjar Alonso, J., Belanche Muñoz Ll., Gavaldá Mestre, R., Gimeno Illa, J.M., López Ibáñez, B., Martín Muñoz, M. \& Sánchez Marré, M. (1998). Aprendizaje automático. Edicions UPC. ISBN: 84-7653-460-4. Barcelona.

García, M.D.; Arnaldos, M.I. \& Presa, J.J. (2007). Guía visual de las prácticas de Zoología. Edit.um Universidad de Murcia. Servicio de Publicaciones. CD-ROM. ISBN: 978-84-8371-6731.

Jiménez Valverde, G. (2006). Obtención de notas individuales a partir de una nota de grupo mediante una evaluación cooperativa. Revista Iberoamericana de Educación, 38, 5: 1-14. ISSN: $1681-5653$.

McConnell, D. (2000). Implementing computer supporter cooperative learning. Kogan Page Ltd. ISBN: 0-7494.3135. London.

Romera Lozano, E., Arnaldos Sanabria, M.I., García García, M.D. \& Soler Andrés, A.G. (2003). Elementos prácticos de Zoología. DM Librero Editor. ISBN: 84-8425-337-6.

Topping, K. (1998). Peer assessment between students in college and universities. Review of Educational Research, 68 (3): 249-276. ISSN: 0034-6543.

Ubero, N., Arnaldos, M.I., Clemente, E., Presa, J.J. \& García, M.D. (2008). La Zoología como materia convergente: un proceso abierto. En: Obra colectiva. III Jornadas sobre el Espacio Europeo de Educación Superior: "Avanzando hacia Bolonia". CD. Edit.um. ISBN: 978-84-8371-743-1. 


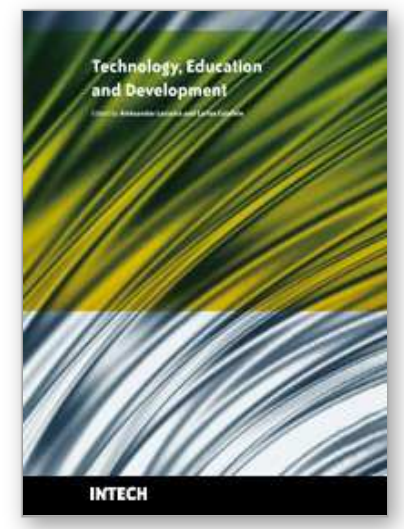

\author{
Technology Education and Development \\ Edited by Aleksandar Lazinica and Carlos Calafate
}

ISBN 978-953-307-007-0

Hard cover, 528 pages

Publisher InTech

Published online 01, October, 2009

Published in print edition October, 2009

The widespread deployment and use of Information Technologies (IT) has paved the way for change in many fields of our societies. The Internet, mobile computing, social networks and many other advances in human communications have become essential to promote and boost education, technology and industry. On the education side, the new challenges related with the integration of IT technologies into all aspects of learning require revising the traditional educational paradigms that have prevailed for the last centuries. Additionally, the globalization of education and student mobility requirements are favoring a fluid interchange of tools, methodologies and evaluation strategies, which promote innovation at an accelerated pace. Curricular revisions are also taking place to achieved a more specialized education that is able to responds to the society's requirements in terms of professional training. In this process, guaranteeing quality has also become a critical issue. On the industrial and technological side, the focus on ecological developments is essential to achieve a sustainable degree of prosperity, and all efforts to promote greener societies are welcome. In this book we gather knowledge and experiences of different authors on all these topics, hoping to offer the reader a wider view of the revolution taking place within and without our educational centers. In summary, we believe that this book makes an important contribution to the fields of education and technology in these times of great change, offering a mean for experts in the different areas to share valuable experiences and points of view that we hope are enriching to the reader. Enjoy the book!

\title{
How to reference
}

In order to correctly reference this scholarly work, feel free to copy and paste the following:

Maria-Isabel Arnaldos and Maria-Dolores Garcia (2009). ETCS Experiences in Zoology: Under and Postgraduate Courses, Technology Education and Development, Aleksandar Lazinica and Carlos Calafate (Ed.), ISBN: 978-953-307-007-0, InTech, Available from: http://www.intechopen.com/books/technologyeducation-and-development/etcs-experiences-in-zoology-under-and-postgraduate-courses

\section{INTECH}

open science | open minds

\author{
InTech Europe \\ University Campus STeP Ri \\ Slavka Krautzeka 83/A \\ 51000 Rijeka, Croatia \\ Phone: +385 (51) 770447 \\ Fax: +385 (51) 686166
}

\author{
InTech China \\ Unit 405, Office Block, Hotel Equatorial Shanghai \\ No.65, Yan An Road (West), Shanghai, 200040, China \\ 中国上海市延安西路65号上海国际贵都大饭店办公楼 405 单元 \\ Phone: +86-21-62489820 \\ Fax: +86-21-62489821
}


www.intechopen.com 
(C) 2009 The Author(s). Licensee IntechOpen. This chapter is distributed under the terms of the Creative Commons Attribution-NonCommercial-ShareAlike-3.0 License, which permits use, distribution and reproduction for non-commercial purposes, provided the original is properly cited and derivative works building on this content are distributed under the same license. 